\title{
The role of phosphodiesterase activity on the temperature- dependent responses of calf cardiac vein
}

\author{
Nurullahoglu ZU \\ Department of Biology, Faculty of Art and Science, Marmara University, Istanbul, Turkey. \\ nulya28@hotmail.com
}

\begin{abstract}
Objective: To evaluate the role of phosphodiesterase (PDE) activity in the cooling (to $28^{\circ} \mathrm{C}$ ) and warming $\left(41^{\circ} \mathrm{C}\right)$-induced effects of carbachol on calf cardiac vein.

Material and methods: Rings obtained from calf hearts were suspended in organ baths containing $25 \mathrm{ml}$ of Krebs-Henseleit solution, maintained at $37{ }^{\circ} \mathrm{C}$, continuously gassed with $95 \% \mathrm{O}_{2}-5 \% \mathrm{CO}_{2}$. At the end of the resting period the preparations were contracted with carbachol $\left(10^{-9}-3 \times 10^{-4} \mathrm{M}\right)$, at $37^{\circ} \mathrm{C}$. The same protocol was repeated at $28{ }^{\circ} \mathrm{C}$ and $41^{\circ} \mathrm{C}$ after the preparations were allowed to equilibrate at this temperature for $60 \mathrm{~min}$. In order to analyze the role of PDE activity in the cooling-and warming-induced vascular response, carbachol $\left(10^{-9}-3 \times 10^{-4} \mathrm{M}\right)$ was applied in the presence of cilostazol $\left(10^{-6} \mathrm{M}\right)$, IBMX $\left(10^{-6} \mathrm{M}\right)$ and rolipram $\left(10^{-6} \mathrm{M}\right)$, respectively. Results: The sensitivity of carbachol was significantly lower during cooling, and higher during warming. Cooling to 28 and warming to $41^{\circ} \mathrm{C}$, after treatment with IBMX, cilostazol or rolipram, significantly decreased the sensitivity to carbachol $(p<0.05)$.

Conclusion: The results of the present study suggest that PDE activity plays an essential role in cooling-and warming-induced changes of calf cardiac vein treated with carbachol (Tab. 1, Fig. 2, Ref. 34). Text in PDF www.elis.sk.

Key words: cardiac vein, carbachol, phosphodiesterase enzyme, cooling, warming.
\end{abstract}

Contractions of vascular smooth muscles to different agents are modulated by several factors, including temperature. Most of the previous studies examining the effect of temperature on smooth muscle responses to vasoactive agents have focused on the effect of cooling and information on warming is rather limited. Experimental evidence shows that cooling affects reactivity of cutaneous and noncutaneous vessels $(1,2)$. It was reported that moderate cooling increased the response of human $(3,4)$ and dog (5) cutaneous veins to sympathetic nerve stimulation, adrenergic and purinergic agonists. In contrast to the effect of cooling on smooth muscle reactivity to contractile agents, the influence of physiologically relevant increases in temperature above $37^{\circ} \mathrm{C}$ on vascular reactivity to vasoactive agents is unclear because of limited information and disparate results. In canine cutaneous veins, heating to temperature above $37^{\circ} \mathrm{C}$ has variable effects on the responses to contractile agents, suggesting that effects of warming may be agent spesific $(6,7)$. Moreover, Padilla et al. (8) reported that in rabbit femoral artery, warming increased the vasoconstrictor response to potassium, endothelin-1, and norepinephrine, and the characteristics of this increase varied depending on the vasoconstrictor used.

Department of Biology, Faculty of Art and Science, Marmara University, Istanbul, Turkey.

Address for correspondence: Z.U. Nurullahoglu, Department of Biology, Faculty of Art and Science, Marmara University, Istanbul, Turkey.

Acknowledgments: The author is grateful to KE Nurullahoglu Atalik for helping in the laboratory and also for statistical analysis.
It is known that cyclic nucleotide monophosphates cyclic AMP (cAMP) and cyclic GMP (cGMP) are important endogenous mediators of several processes, including smooth muscle motility $(9,10)$. Cyclic nucleotides are synthesized from the corresponding nucleoside triphosphates by the activity of adenylyl and guanylyl cyclases. The increase in cAMP or cGMP triggers a signal transduction cascade encompassing the activation of cyclic nucleotidedependent protein kinases (cAK, cGK), subsequent phosphorylation of the actin-myosin system, as well as $\mathrm{Ca}^{2+}$ channels and ATP-driven $\mathrm{Ca}^{2+}$ pumps located in the outer cell membrane or the membrane of the sarcoplasmic reticulum. This cascade leads to a reduction in cytosolic $\mathrm{Ca}^{2+}$ and, finally, to smooth muscle relaxation. Cyclic nucleotides are degraded by phosphodiesterase (PDE) isoenzymes, a heterogeneous group of hydrolytic enzymes. Phosphodiesterases are classified according to their preferences for cAMP or/and cGMP, kinetic parameters of cyclic nucleotide hydrolysis, sensitivity to the inhibition by various compounds, allosteric regulation by other molecules and chromatographic behaviour on anion exchange columns. Eleven families of PDE isoenzymes have been distinguished: $\mathrm{Ca}^{2+} /$ calmodulin-stimulated PDE (PDE1), cGMP-stimulated PDE (PDE2), cGMP-inhibited PDE (PDE3), cAMP-specific PDE (PDE4), cGMP-specific PDE (PDE5) and the cGMP-binding, cGMP-specific PDE of mammalian rods and cones (PDE6). While PDE7 (cAMP-high affinity) and PDE8 (IBMX-insensitive) have preferred selectivity for cAMP, PDE9 exclusively degrades cGMP. PDE isoenzymes 10 and 11 can inactivate both cAMP and cGMP. Some of these isoenzyme families consist of more than one gene and some genes are 
alternatively spliced so that more than 50 isoenzymes or variants have been identified. Some PDE genes are also variably expressed in different tissues $(11,12)$. Since the distribution and functional significance of PDE isoenzymes can vary in different tissues, isoenzyme-selective inhibitors have the potential to exert specific effects on the target tissue. To date, six out of the 11 PDE isoenzymes have been proven to be of pharmacological importance: PDE1, PDE2, PDE3, PDE4, PDE5 and PDE11 (13). Phosphodiesterases represent a target for many current pharmacotherapies and as such have major clinical appeal. The major PDEs present in vascular smooth muscles are the cGMP-inhibited PDE (PDE3), the cAMPspecific PDE (PDE4), and the major cGMP-hydrolyzing enzyme PDE5 (14-17). The PDE4 family, which specifically hydrolyzes cAMP and is insensible to cGMP, is predominantly expressed in myometrium (18), but also in the smooth muscle of the airways and in inflammatory cells (19).

Thus, despite current research to determine the effects of temperature on vascular reactivity of different animal species, studies about PDE activity remain incomplete and there are no studies that analyze the effects of PDE activity on temperature-dependent responses of calf cardiac vein.

The aim of the present study was to determine the role of PDE activity on the cooling and warming-induced responses of calf cardiac vein. For this study, the calf cardiac vein was selected because it is a noncutaneous vessel and is easily accessible. Therefore, a non-selective PDE inhibitor IBMX, a PDE3A inhibitor cilostazol and a PDE4 inhibitor rolipram were used in preparations constricted with carbachol during cooling and warming.

\section{Material and methods}

\section{Tissue preparations}

Calf hearts were obtained from a slaughterhouse and were immediately placed in Krebs-Henseleit solution. Segments of the great cardiac vein were removed and cut into rings $2.5 \mathrm{~mm}$ in length. Care was taken not to damage the endothelium. Each ring was mounted in $25 \mathrm{ml}$ organ baths containing Krebs-Henseleit Solution (KHS), aerated with $95 \% \mathrm{O}_{2}$ and $5 \% \mathrm{CO}_{2}$. KHS wascomposed of (mM): $\mathrm{NaCl} 119, \mathrm{KCl} 4.70, \mathrm{MgSO}_{4} 1.50, \mathrm{KH}_{2} \mathrm{PO}_{4} 1.20$, $\mathrm{CaCl}_{2}$ 2.50, $\mathrm{NaHCO}_{3} 25$, Glucose 11. Changes in isometric tension were recorded by a force-displacement transducer (BIOPAC MP36, Santa Barbara, California, USA) connected through amplifiers to a ITBS08 Integrated Tissue Bath System (Commat, Ankara, Turkey). The tissues were allowed to equilibrate for $60 \mathrm{~min}$ under a resting tension of $1 \mathrm{~g}$ with repeated washing every $15 \mathrm{~min}$.

\section{Experimental procedure}

First, cumulative concentration-response curves were determined in calf cardiac vein for carbachol $\left(10^{-9}-3 \times 10^{-4} \mathrm{M}\right)$ at $37^{\circ} \mathrm{C}$. Then, another set of experiments was designed to determine the effect of cooling on the carbachol-induced contractile responses. After the first concentration-response curve was completed, preparations were washed and allowed to reestablish resting tension before being cooled. When preparations stabilized (30 min), bath temperature was decreased to $28{ }^{\circ} \mathrm{C}$. Preparations were al- lowed to equilibrate at this temperature for $1 \mathrm{~h}$ before a second concentration-response curve was determined. In order to analyse the role of phosphodiesterase activity in the cooling induced vascular response, concentration-response curves to carbachol were obtained in the presence of IBMX $\left(10^{-6} \mathrm{M}\right)$, cilostazol $\left(10^{-6} \mathrm{M}\right)$ and rolipram $\left(10^{-6} \mathrm{M}\right)$, respectively. The preparations were incubated for $20 \mathrm{~min}$ with each agent.

In order to analyse the role of PDE activity in the warming induced vascular response, concentration-response curves to carbachol-were obtained at $41^{\circ} \mathrm{C}$.

Only one agent was tested in each preparation.

\section{Statistical analysis}

Concentrations of the contractile agents causing $50 \%$ of the maximal response $\left(\mathrm{EC}_{50}\right)$ were calculated from each individual concentration-response curve. Maximal responses and $\mathrm{EC}_{50}$ values for curves obtained before (control) and during cooling and warming (control II) and in the presence of IBMX $\left(10^{-6} \mathrm{M}\right)$, cilostazol $\left(10^{-6} \mathrm{M}\right)$ and rolipram $\left(10^{-6} \mathrm{M}\right)$, during cooling and warming were compared by using paired and unpaired Student's t test. Statistical significance was set at $\mathrm{p}<0.05$.

\section{Drugs}

Carbachol chloride, IBMX, cilostazol and rolipram were obtained from Sigma (St. Louis, MO, USA). Carbachol chloride was dissolved in distilled water and the stock solutions of others were dissolved in dimethyl sulphoxide; DMSO.

\section{Results}

Figure 1 shows the effects of carbachol $\left(10^{-9}-3 \times 10^{-4} \mathrm{M}\right)$ on calf cardiac vein rings at $37^{\circ} \mathrm{C}, 28^{\circ} \mathrm{C}$ (cooling), and in the presence of IBMX $\left(10^{-6} \mathrm{M}\right)$, cilostazol $\left(10^{-6} \mathrm{M}\right)$ and rolipram $\left(10^{-6} \mathrm{M}\right)$ during cooling. At $37^{\circ} \mathrm{C}$, carbachol produced concentration-dependent contractions. The $\mathrm{EC}_{50}$ value was found as $5.4 \pm 0.3$. The sensitivity, but not the maximal response (data not given), of carbachol was significantly lower $(4.6$ times; $\mathrm{p}<0.05)$ at $28^{\circ} \mathrm{C}$ than at $37^{\circ} \mathrm{C}$.

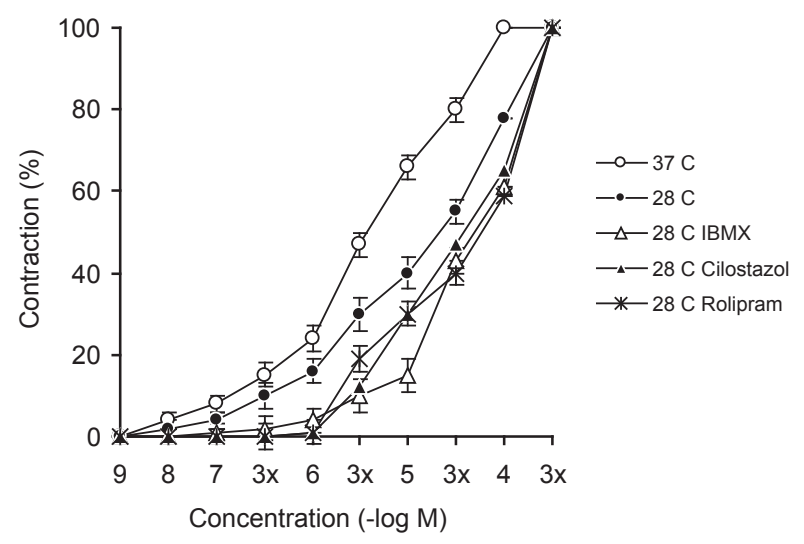

Fig. 1. Carbachol concentration-response curves of control I $\left(37^{\circ} \mathrm{C}\right)$, control II $\left(28^{\circ} \mathrm{C}\right)$ and in the presence of IBMX, cilostazol and rolipram at $28^{\circ} \mathrm{C}$ in calf cardiac vein. Each point is the mean $\pm S E$ of 6 experiments. 
Tab. 1. The EC50 values for carbachol in calf cardiac vein at $28,41^{\circ} \mathrm{C}$ and in the presence of IBMX, cilostazol and rolipram at 28 and $41^{\circ} \mathrm{C}$. Data are means \pm SEM.

\begin{tabular}{lcc} 
EC50 & $28^{\circ} \mathrm{C}$ & $41{ }^{\circ} \mathrm{C}$ \\
Control & $25.0 \pm 0.2$ & $0.7 \pm 0.2$ \\
IBMX & $40.0 \pm 0.4^{*}$ & $4.0 \pm 0.3^{*}$ \\
Cilostazol & $30.0 \pm 0.2^{* *}$ & $3.4 \pm 0.5^{* *}$ \\
Rolipram & $50.0 \pm 0.3^{* *}$ & $4.8 \pm 0.2^{* *}$ \\
\hline$*(\mathrm{p}<0.05)$ compared to control value at $28^{\circ} \mathrm{C}, * *(\mathrm{p}<0.05)$ & compared to control \\
value at $41^{\circ} \mathrm{C}$ &
\end{tabular}

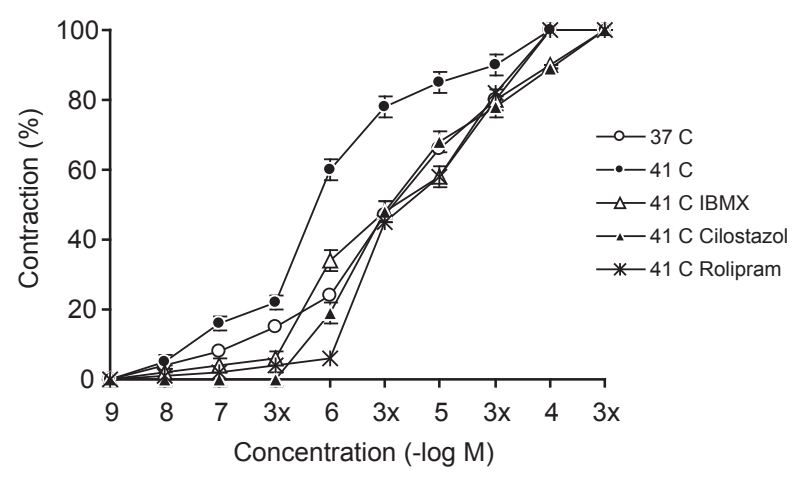

Fig. 2. Carbachol concentration-response curves of control I $\left(37^{\circ} \mathrm{C}\right)$, control II $\left(41^{\circ} \mathrm{C}\right)$ and in the presence of IBMX, cilostazol and rolipram at $41^{\circ} \mathrm{C}$ in calf cardiac vein. Each point is the mean $\pm \mathrm{SE}$ of 6 experiments.

Cooling to $28^{\circ} \mathrm{C}$ after treatment with IBMX $\left(10^{-6} \mathrm{M}\right)$, cilostazol $\left(10^{-6} \mathrm{M}\right)$ or rolipram $\left(10^{-6} \mathrm{M}\right)$, significantly decreased the sensitivity to carbachol (Tab. 1).

Figure 2 shows the effects of carbachol $\left(10^{-9}-3 \times 10^{-4} \mathrm{M}\right)$ on calf cardiac vein rings at $37^{\circ} \mathrm{C}, 41^{\circ} \mathrm{C}$ (warming), and in the presence of IBMX $\left(10^{-6} \mathrm{M}\right)$, cilostazol $\left(10^{-6} \mathrm{M}\right)$ and rolipram $\left(10^{-6} \mathrm{M}\right)$, during warming. The sensitivity, but not the maximal response (data not given), of carbachol was significantly higher ( 7.7 times; $\mathrm{p}<0.05$ ) at $41^{\circ} \mathrm{C}$ than at $37^{\circ} \mathrm{C}$. Warming to $41^{\circ} \mathrm{C}$ after treatment with IBMX $\left(10^{-6} \mathrm{M}\right)$, cilostazol $\left(10^{-6} \mathrm{M}\right)$ or rolipram $\left(10^{-6} \mathrm{M}\right)$, significantly decreased the sensitivity to carbachol (Tab. 1).

\section{Discussion}

In the present work, we studied the effects of different PDE families in the responses mediated by the cyclic nucleotides in calf cardiac vein during cooling and warming. The precise regulation of the intracellular levels of cyclic nucleotides (cAMP and cGMP) plays an important role in many physiological processes, including vascular smooth muscle contractility (20).

The cardiac vein is an easily accesible noncutaneous blood vessel and the role of PDE activity on cooling and warming-induced effects of carbachol-induced contractions on this vessel has not been studied before. Coronary venous system (cardiac veins) collects one-third blood of the coronary circulation and is considered to be an important site for the blood-tissue exchange of water and nutrients, as well as a possible determinant of ventricular distensibility. The temperature utilized in this study; $28^{\circ} \mathrm{C}$, for cooling was considered to be "moderate cooling" and $41^{\circ} \mathrm{C}$, "moderate warming" temperature accordingly to previous studies (21-24).
In the present study, we investigated the role of PDE activity on the carbachol-induced contractions of calf cardiac vein, during cooling and warming. The results indicate that cooling decreased and warming increased the sensitivity to carbachol. The use of a broad-spectrum PDE inhibitor IBMX, a PDE3 inhibitor cilostazol, the prototype selective PDE4 inhibitor rolipram (25) resulted in a clear reduction in the sensitivity of carbachol during cooling and warming. This suggests that the mechanism of carbachol-induced contraction in calf cardiac vein during cooling and warming involves both PDE3 and PDE4. To my knowledge, this is the first study to show the effects of PDE inhibition of calf cardiac vein contracted with carbachol. In different studies it is reported that cooling (to $28^{\circ} \mathrm{C}$ ) induced subsensitivity (21) and warming (to 41 $\left.{ }^{\circ} \mathrm{C}\right)$ induced supersensitivity $(22,23)$ to carbachol in calf cardiac vein. In these studies, it has also been observed that endothelial nitric oxide does not play a role in the decreased sensitivity of noncutaneous vessels to contractile agents during cooling. However, the mechanism underlying the effects of cooling and warming on noncutaneous vessels to contractile agents is not clear.

As cyclic nucleotides can modulate the vascular smooth muscle tone, the PDEs have become an attractive target for drug development, due to the existence of different PDE isozymes which are differently regulated and distinctly expressed in the cardiovascular system. PDEs hydrolyze cAMP and cGMP and control the concentration of them. The mammalian PDEs are grouped into 11 broad enzyme families that have different structure, biochemical properties, tissue distribution and pharmacological inhibitors.8 Although PDE1, 2, 3, 10, and 11 hydrolyze both cAMP and cGMP; PDE4, 7 , and 8 are specific for cAMP and PDE5, 6, and 9 are specific for cGMP catabolism. PDEs are regulated through a variety of factors. The PDE1 family is the only PDE that is regulated by $\mathrm{Ca}^{2+} /$ calmodulin. PDE2 is stimulated and PDE3 is inhibited by cGMP. Thus cGMP, via PDE2 and PDE3 can change the balance in the favor of cAMP or itself and plays a critical role in the regulation of cellular cyclic nucleotides levels. PDEs are classified into 11 broad families each having different tissue, cell and subcellular expression (26). In the cardiac tissues, at least 6 different PDE families have been determined, including PDE1, 2, 3, 4, 5, and 8, which prove vital in the regulation of heart functions in both resting and stimulated conditions. Crosstalk exists between cAMP and cGMP at the activity of PDEs. Increased cGMP could either increase cAMP levels by inhibiting PDE3 or decrease it by stimulating PDE2. Therefore, the relative concentration and compartmentalization of these 2 molecules critically determines cardiac functions $(26,27)$.

Cyclic nucleotides regulate fundamental cellular functions in the cardiovascular system. In the heart, intracellular concentrations of cGMP and cAMP controlled by PDEs critically determine cardiac functions (26). The presence of at least 6 PDEs (PDE1, $2,3,4,5$, and 8 ) was recognized in the heart $(26,27)$. However, different expressions and activities of PDE enzymes in the heart have been described among species, tissues, cells and subcellular compartments (28-30). In addition, effects of PDEs inhibitors on cardiac functions has been examined in basal and stimulated conditions in different experimental models (30-34).

In conclusion, the results of the present study demonstrate for the 
first time that PDE inhibitors IBMX, cilostazol and rolipram can affect the contractions to carbachol during cooling and warming in calf cardiac vein. Further studies must be performed to clarify the mechanism of cooling and warming-induced responses in calf cardiac vein.

\section{References}

1. Harker CT, Ousley PJ, Bownan CJ, Porter JM. Cooling augments alpha-2 adrenoceptor mediated contractions in rat tail artery. Am J Physiol 1991; 260: 1160-1171.

2. Bodelsson M, Arneklo-Nobin B, Chester AH, Tadjkarimi S, Törnebrandtl K, Yacoub M. Differential effects of hypothermia on the vascular tone and reactivity of the human coronary artery and graft vessels. J Cardiovasc Surg 1991: 32: 288-294.

3. Bodelsson M, Arneklo-Nobin B, Arneklo-Nobin B, Nobin A, Owman C, Sollerman C, Tornebrandt K. Cooling enhances alpha ${ }_{2}$-adrenoceptor-mediated vasoconstriction in human hand veins. Acta Physiol Scand 1990; 138: 283-291.

4. Harker CT, Bowman CJ, Taylor LM, Jr. Porter JM. Cooling augments human saphenous vein reactivity to electrical stimulation. J Cardiovasc Pharmacol 1994; 23: 453-457.

5. Flavahan NA, Vanhoutte PM. Sympathetic purinergic vasoconstriction and thermosensitivity in a canine cutaneous vein. J Pharmacol Exp Ther 1986; 239: 784-789.

6. Cooke JP, Shepherd JT, Vanhoutte PM. The effect of warming on adrenergic neurotransmission in canine cutaneous vein. Circ Res 1984; 54: $547-553$.

7. Vanhoutte PM, Cooke JP, Lindblad LE, Shepherd JT, Flavahan NA. Modulation of postjunctional $\alpha$-adrenergic responsiveness by local changes in temperature. Clin Sci 1985; 68: 121-123.

8. Padilla J, Garcia-Villalon AL, Fernandez N, Monge L, Gomez B, Dieguez G. Effects of hyperthermia on contraction and dilatation of rabbit femoral arteries. J Appl Physiol 1998; 85: 2205-2212.

9. Rybulkin SD, Yan C, Bornfeld KE, Beavo JA. Cyclic GMP phosphodiesterase and smooth muscle function. Circ Res 2003; 93: 280-291.

10. Maurice DH, Palmer D, Tilley DG, Dunkerley HA, Netherton SJ, Raymond DR, Elbatany HS, Jimmo SL. Cyclic nucleotide phosphodiesterase activity, expression, and targeting cells in the cardiovascular system. Mol Pharmacol 2003; 64: 533-546.

11. Conti M, Jin SL. The molecular biology of cyclic nucleotide phosphodiesterases. Prog Nucleic Acid Res Mol Biol. 1999; 63: 1-38.

12. Essayan DM. Cyclic nucleotide phosphodiesterases. J Allergy Clin Immunol 2001; 108: 671-680.

13. Gupta R, Kumar G, Kumar RS. An update on cyclic nucleotide phosphodiesterase (PDE) inhibitors: phosphodiesterases and drug selectivity. Methods Find Exp Clin Pharmacol 2005; 27: 101-108.

14. Tilley DG, Maurice DH. Vascular smooth muscle cell phosphodiesterase (PDE) 3 and PDE4 activities and levels are regulated by cyclic AMP in vivo. Mol Pharmacol 2002; 62: 497-506.

15. Aizawa T, Wei H, Miano JM, Abe J, Berk BC, Yan C. Role of phosphodiesterase 3 in NO/cGMP-mediated antiinflammatory effects in vascular smooth muscle cells. Circ Res 2003; 93: 406-413.

16. Rybalkin SD, Yan C, Bornfeldt KE, Beavo JA. Cyclic GMP phosphodiesterases and regulation of smooth muscle function. Circ Res 2003; 93: 280-291.
17. Kass DA, Champion HC, Beavo JA. Phosphodiesterase type 5: expanding roles in cardiovascular regulation. Circ Res 2007; 101: 1084-1095.

18. Franova S, Janicek F, Visnovsky J, Dokus K, Zubor P, Sutovska M, Nosalova G. Utero-relaxant effect of selective inhibitor alone and in simultaneous administration with $\beta_{2}$-mimetic on oxytocin-induced contractions in pregnant myometrium. J Obstet Gynaecol Res 2009; 35: 20-25.

19. Burnouf C, Pruniaux MP. Recent advances in PDE4 inhibitors as immunoregulators and anti-inflammatory drugs. Curr Pharm Des 2002; 8: $1255-1296$.

20. Matsumoto T, Kobayashi T, Kamata K. Phosphodiesterases in the vascular system. J Smooth Muscle Res 2003; 39: 67-86.

21. Nurullahoglu-Atalik KE. Role of calcium in contractile responses of calf cardiac vein during cooling. J Smooth Muscle Res 2011; 47: 135-142.

22. Atalik KE, Sahin AS, Ulusoy HB, Dogan N. Warming and response to contractile agents in calf cardiac vein: role of nitric oxide. Fundam Clin Pharmacol 2003; 17: 77-82.

23. Atalik KE, Sahin AS, Dogan N. Warming and response to contractile agents in calf cardiac vein: role of the $\mathrm{Ca}^{2+}, \mathrm{K}_{\mathrm{Ca}}{ }^{2+}$, and $\mathrm{Na}^{+}$ion channel blockers. Methods Find Exp Clin Pharmacol 2005; 27: 653-657.

24. Atalik KE, Kiliç M, Dogan N. Role of the nitric oxide on diazoxideinduced relaxation of the calf cardiac vein and coronary artery during cooling. Fundam Clin Pharmacol 2009; 23: 271-277.

25. Kaasik A, Ohisalo JJ. Membrane-bound phosphodiesterases in rat myocardium. J Pharm Pharmacol 1996; 48: 962-964.

26. Francis SH, Blount MA, Corbin JD. Mammalian cyclic nucleotide phosphodiesterases: molecular mechanisms and physiological functions. Physiol Rev 2011; 91: 651-690.

27. Zaccolo M, Movsesian MA. cAMP and cGMP signaling cross-talk: role of phosphodiesterases and implications for cardiac pathophysiology. Circ Res 2007; 100: 1569-1578.

28. Miller CL, Yan C. Targeting cyclic nucleotide phosphodiesterase in the heart: therapeutic implications. J Cardiovasc Transl Res 2010; 3: 507-515.

29. Liu H, Maurice DH. Expression of cyclic GMP-inhibited phosphodiesterases 3A and 3B (PDE3A and PDE3B) in rat tissues: differential subcellular localization and regulated expression by cyclic AMP. Br J Pharmacol 1998; 125: 1501-1510.

30. Lakics V, Karran EH, Boess FG. Quantitative comparison of phosphodiesterase mRNA distribution in human brain and peripheral tissues. Neuropharmacology 2010; 59: 367-374.

31. Juan-Fita MJ, Vargas ML, Hernández J. Comparative actions of diazepam and other phosphodiesterase inhibitors on the effects of noradrenaline in rat myocardium. Pharmacol Toxicol 2003; 93: 23-28.

32. Jurevicius J, Skeberdis VA, Fischmeister R. Role of cyclic nucleotide phosphodiesterase isoforms in cAMP compartmentation following beta2adrenergic stimulation of $\mathrm{ICa}, \mathrm{L}$ in frog ventricular myocytes. J Physiol 2003; 551 (pt 1): 239-252.

33. Kaumann A, Semmler AB, Molenaar P. The effects of both noradrenaline and CGP12177, mediated through human beta1 -adrenoceptors, are reduced by PDE3 in human atrium but PDE4 in CHO cells. Naunyn Schmiedebergs Arch Pharmacol 2007; 375: 123-131.

34. Galindo-TovarA, Kaumann AJ. Phosphodiesterase-4 blunts inotropism and arrhythmias but not sinoatrial tachycardia of (2)-adrenaline mediated through mouse cardiac beta(1)-adrenoceptors. Br J Pharmacol 2008; 153 : $710-720$.

Received December 13, 2012. Accepted April 8, 2013. 